\title{
Rithi Ranjana: reconstructing crop economy based on archaeobotanical evidence and radiocarbon dates from an Early Iron Age site in semi-arid Vidarbha, Maharashtra, India
}

\author{
Himani Patel ${ }^{1,2, *}$, Anil K. Pokharia ${ }^{1, *}$, Nihildas, $N^{3}$, Niraj Rai ${ }^{1}$ and \\ Rajeshwar P. Sinha ${ }^{2}$ \\ ${ }^{1}$ Birbal Sahni Institute of Palaeosciences, 53 University Road, Lucknow 226007 , India \\ ${ }^{2}$ Centre of Advance Study in Botany, Banaras Hindu University, Varanasi 221 005, India \\ ${ }^{3}$ Institute of Archaeology, Archaeological Survey of India, Greater Noida 201 310, India
}

\begin{abstract}
We present results of the macrobotanical remains from an Early Iron Age site Rithi Ranjana in the Vidarbha region, Maharashtra, India. Analysis of 34 floated samples indicates that the likely staple foodgrains were Oryza sativa, Hordeum vulgare and Triticum aestivum. Besides, few minor crops, pulses and oil/fibre-yielding plants have been retrieved. In addition, there is evidence of fruits like Carissa sp., Ziziphus nummularia and Emblica sp., which may have been gathered by the ancient settlers for consumption. The macro-botanical finds indicate the presence of winter and summer crops. Few weeds and other wild taxa as an admixture with the above economically important remains were also retrieved. The AMS radiocarbon dates of the plant remains and recovered archaeological artifacts support the affirmation of Early Iron Age cultural period at the site.
\end{abstract}

Keywords: Archaeobotany, crop economy, microbotanical remains, radiocarbon dates, semi-arid region.

VIDARBHA is the present-day eastern part of Maharashtra, India, and includes 11 eastern-most districts of the state. The town of Nagpur is the most administrative centre of the region. This is a lesser known region for multidisciplinary archaeological research. Absence of direct radiocarbon-dated remains has been the limitation to advance chronological framework of an Iron Age site in this region. Agricultural evidence can be seen in the form of macrobotanical remains, agricultural tools and implements recovered during excavations. The beginnings of the Iron Age in India is a matter of debate. Archaeological finds from the Indian subcontinent reveal that iron appeared in a diverse cultural context and this poses an issue regarding the exact date of the beginning of the Iron Age in India. Early Iron Age in Vidarbha is determined

*For correspondence. (e-mail: patelhim412@gmail.com; pokharia.anil@gmail.com) on the basis of occurrence of iron implements in the stratigraphy accorded with carbon dates. It is preceded by Vidarbha Chalcolithic. Thus, the occurrence of iron implements along with black- and redware pottery in the stratigraphy is considered as Early Iron Age in Maharashtra, which is associated with megalithic culture. Earlier excavations at Raja Nal-Ka-Tila and Lahuradewa in Middle Ganga Valley, North India, and Komaranhali and Hallur in south India have provided evidence which allows placing the Iron Age to be the second half of the second millennium $\mathrm{BC}$ in the Indian subcontinent ${ }^{1}$. The Early Iron Age culture of Vidarbha has been well documented and studied by many scholars for more than a century ${ }^{2-16}$. The Early Iron Age is represented by non-megalithic sites like Kaudinyapur ${ }^{17}$, Paunar $^{18}$, Arni ${ }^{19}$, KahaliBrahmapuri $^{20}$ and Adam $^{21}$. At these sites, Megaliths or megalith building-related concepts do not appear to have been part of life, though these communities were synchronous with and sympatric to the Early Iron Age megalithic culture. Iron is ubiquitous in both cultural traditions of Vidarbha but the megalith builders are regarded as pioneers in the introduction of iron technology 22,23 . This development of iron, in particular, is dated to c. 700-500 BCE based on 30 radiocarbon dates from Takalghat, Naikund, Khairwada and Bhagimohari ${ }^{24}$. Iron technology was introduced relatively late in Vidarbha, much later than its adoption in the northern and southern regions of India at 1800-1600 and 2300-2000 BCE respectively ${ }^{25}$. It is still unclear whether the megalith builders and nonmegalithic Early Iron Age culture of Vidarbha exchanged iron artifacts, as all megalithic sites excavated so far in the region have yielded iron artifacts. These items are almost always associated with human burials, but the iron objects excavated from both megalithic burial sites and habitation-cum-burial sites were mostly utilitarian. They can be categorized as agricultural tools, weapons, vessels and horse-harnessing equipment like stirrups and horse bits. Naikund is a highly significant site in this regard as 


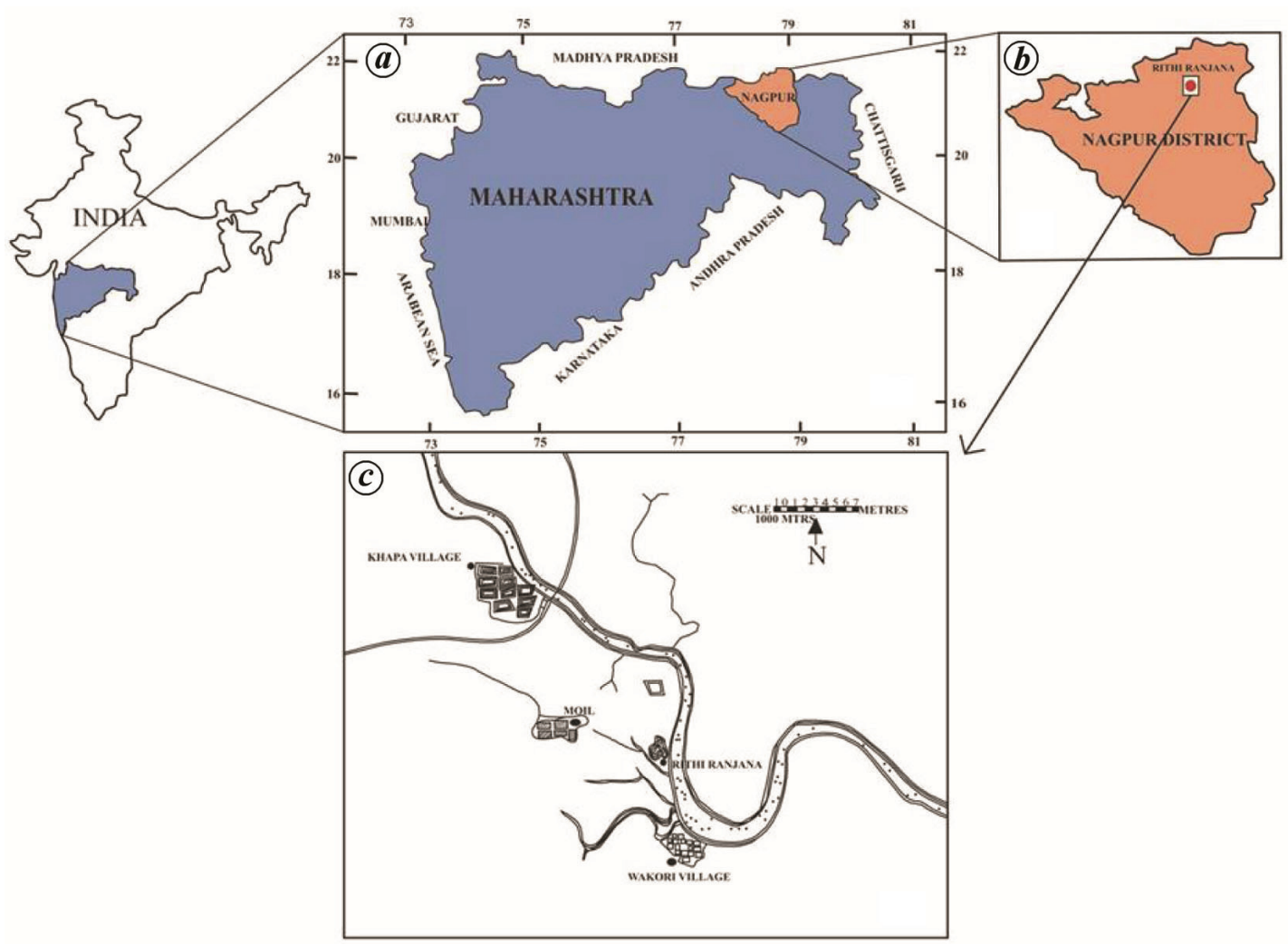

Figure 1. $\boldsymbol{a}$, Map of Maharashtra, India showing archaeological site in Nagpur. $\boldsymbol{b}$, Nagpur region showing the study site Rithi Ranjana. $c$, Location map of the study site.

an iron smelting furnace was uncovered, demonstrating indigenous iron production ${ }^{8}$. It is noteworthy that the easternmost districts of Vidarbha are rich in high quality iron, ranging from $54 \%$ to $65 \%$ (refs 22 and 24). Using this feature, Gogte ${ }^{23}$ reconstructed the process of iron smelting and visualization of the probable structure of a furnace $^{23}$. An iron dagger with a copper hilt and small, dome-shaped bells of copper with iron tongues were part of the grave goods at Naikund ${ }^{23}$. This study aims to present agricultural development based on directly dated carbonized plant remains, to enrich dating of the cultural sequence, and compare the information on agriculture remains from other Early Iron Age sites in the north, east, west and southwest of India.

\section{Archaeological, geomorphic and geological settings}

The archaeological site Rithi Ranjana (lat. $21^{\circ} 24^{\prime} 129^{\prime \prime} \mathrm{N}$; long. $79^{\circ} 00^{\prime} 093^{\prime \prime} \mathrm{E}$ ) is situated on the right bank of River Kanhan, a tributary of the Wainganga, and is about $2 \mathrm{~km}$ within Gumgaon MOIL (Manganese Ore India Limited) near village Khapa, Nagpur district, Maharashtra (Figure 1). The word 'Rithi Ranjana' means 'abandoned pots'. It is $37 \mathrm{~km}$ northwest of Nagpur district. The region is rich in mineral deposits such as manganese and iron ore.
The mound of Rithi Ranjana is roughly oval shaped, measures approximately $100 \mathrm{~m} \times 100 \mathrm{~m}$ north-south and east-west respectively, covering an area of 10,000 sq. m or 1 acre. However, the northern and eastern sides are partially damaged due to flood activities of river Kanhan, thus leaving an area of $90 \mathrm{~m}$ intact on the eastern side. Twelve trenches of $10 \mathrm{~m} \times 10 \mathrm{~m}$ comprising 24 quadrants were opened in different part of the mound, exposing an area of $600 \mathrm{sq} . \mathrm{m}$. These are A1/I\&II, ZA1, ZA2, YA1, YA3/II, YA4/III, YB2/II, YB3III, YB4/IV, XB1/I, $\mathrm{XA} 1 / \mathrm{I} \& \mathrm{II}$ and $\mathrm{ZC} 3 / \mathrm{II}$ located at the centre, southwestern, northwestern and northeastern sides of the mound (Figure $2 a-h)$. Four of these trenches (XB1, ZA1, YA3 and ZC3) were excavated up to the natural soil (Figure $3 a$ and $b$ ) while two (A1/I\&II in Figure $3 c$ and ZA2/II) were excavated up to $2 \mathrm{~m}$, while the others were exposed up to 0.50-1 m depth. The maximum thickness of the cultural deposit was recorded as $2.87 \mathrm{~m}$ in XB1/I (309.34 amsl), YA3/II (309.43 amsl), ZA1 (309.57) and ZC3/III (309.62 amsl). The trench ZA1 was excavated in total size of $10 \mathrm{~m} \times 10 \mathrm{~m}$ area till layer 8 and last two layers, i.e. 9 and 10 were excavated in $5.5 \mathrm{~m} \times 5.5 \mathrm{~m}$ area, falling in the northeastern area of ZA1. Further, an area covering $25 \mathrm{~m} \times 20 \mathrm{~m}$ in the middle of the mound was exposed horizontally to understand the nature of settlement. The mound comprising 600 sq. $\mathrm{m}$ areas out of 10,000 sq. $m$ area was subjected to excavation. 


\section{RESEARCH ARTICLES}

Vidarbha (lat. $19^{\circ} 22^{\prime} \mathrm{N}$ and long. $76^{\circ} 81^{\prime} \mathrm{E}$ ), the northeastern region of Maharashtra, is bounded by Madhya Pradesh to the north, Andhra Pradesh to the south, Chhattisgarh to the east, and Jalgaon, Jalna, Hingoli and Nanded districts of Maharashtra to the west. It has the Satpuda and Mahadeo Hills in the north and a general slope towards the south, owing to the formations of the Deccan Traps. The Vidarbha region is a fertile plateau which lies between Melghat in the Satpura range in the north and Balaghat in the Ajanta range in the south, also known as Payanghat ${ }^{26}$. The region is drained by Wardha, Wainganga, Penganga and Purna rivers. Wardha and Wainganga streams start in Satpura district, Madhya Pradesh, and run parallel to one another; reputed for horticultural and pastoral practices. Wainganga is the biggest stream in the area. The main tributary of Wainganga is Penganga in the west, which drains the regions of Buldhana and Yeotmal. The tributaries of Wardha are Kar, Wenna, Erai, Madu, Bembla and Penganga. They bring significant amount of alluvial soil to their banks.

Maharashtra is extensively covered with igneous rocks or Trap basalt formed by molten magma known as the

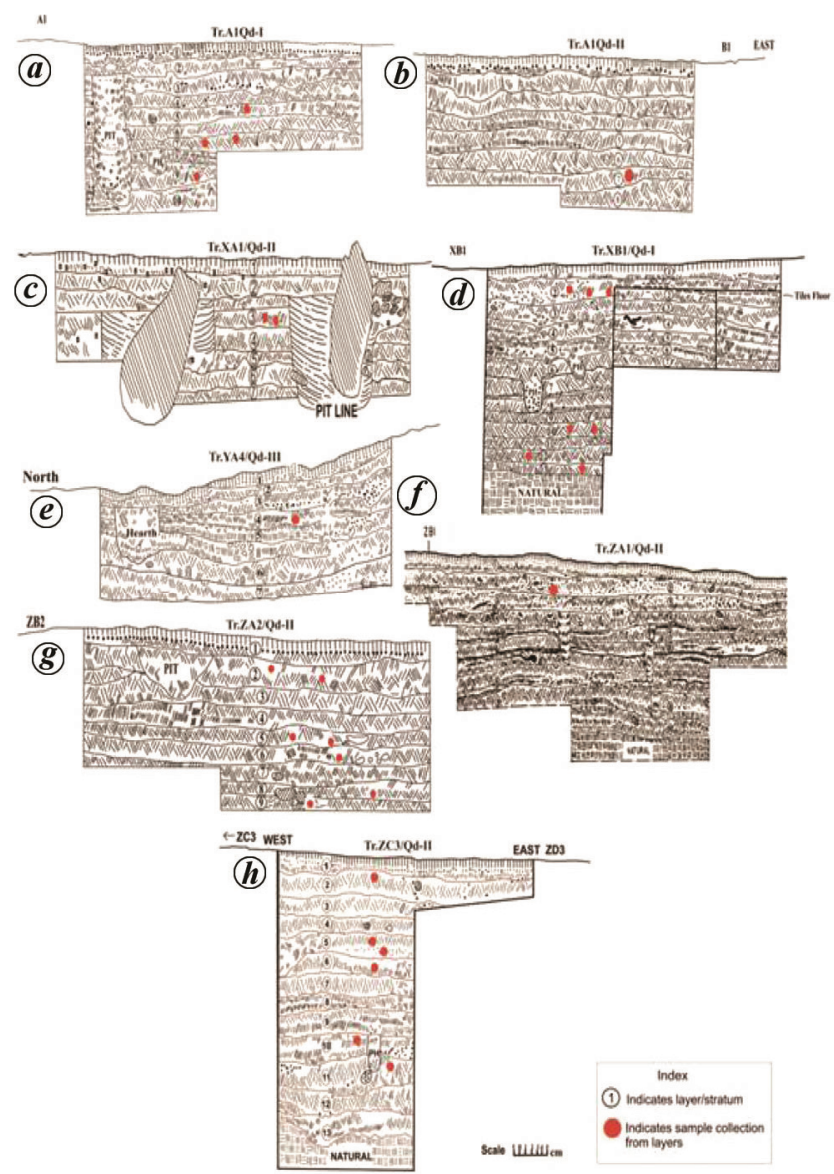

Figure $2 \boldsymbol{a}-\boldsymbol{h}$. Section drawing of different trenches from which carbonized remains were collected for the present study at Rithi Ranjana.
Deccan Traps. They cover all parts of Maharashtra except the eastern districts of Vidarbha region and the districts of Sindhudurg and Ratnagiri ${ }^{26}$. While Deccan Traps cover the districts of Nagpur and Wardha, Nagpur city forms their northeastern boundary. The other regions of Vidarbha fall under the formations of Archean and Gondwana. It is important to note here that basaltic plateau of Deccan Traps itself rests above the Archaean base. The Archaean are Pre-Cambrian rock formations which are composed of crystalline gneisses and schist. These are, in turn, also overlain by metamorphosed sedimentary rocks of the Dharwad system which spreads over Nagpur and Bhandara districts. The greater part of the soils in Vidarbha are dark, dull darker or ruddy, alluvial/laterite (Vidarbha area) in shade and consequently are called black cotton soils. The dark cotton soils are substantial in surface and have a high level of the earth. They have sufficient amount of mineral components and micronutrients, and hence are considered useful for plant nourishment. The dark cotton soils are one of the most seasoned gatherings of soils since the Tertiary.

\section{Climate and vegetation}

The climate of Vidarbha is characterized by hot summers and general dryness throughout the year, except during the southwest monsoon season. During summer, the mean daily maximum temperature of the district is $45^{\circ} \mathrm{C}$ while the mean daily minimum temperature is $27.5^{\circ} \mathrm{C}$ and in winter the temperature is between $12^{\circ} \mathrm{C}$ and $14^{\circ} \mathrm{C}$. The average rainfall of this region is $846 \mathrm{~mm}$ (ref. 27). However, $1736 \mathrm{~mm}$ rainfall in some areas is noteworthy ${ }^{28}$. The Vidarbha region receives rainfall during the northeast monsoon. However, it receives almost $87 \%$ of its annual rainfall from the southwest monsoon between June and September ${ }^{26}$.

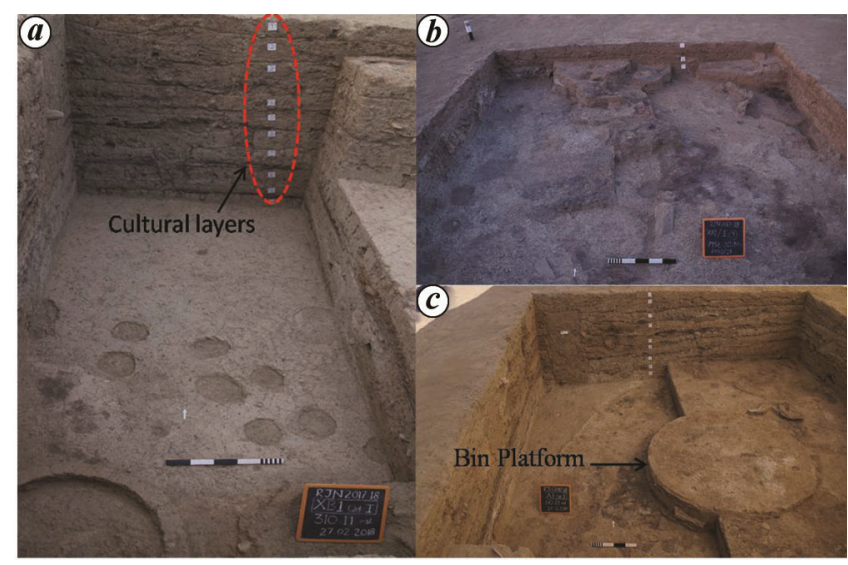

Figure 3. General layout of trenches (a) XB1, (b) XA1, (c) A1 showing cultural layers, postholes and bin. 
RESEARCH ARTICLES

Table 1. Macrobotanical remains recorded from Rithi Ranjana, Vidarbha, Maharashtra, India

\begin{tabular}{|c|c|c|c|c|c|c|c|c|c|c|}
\hline Trench & AI & XA1 & $\mathrm{XB} 1$ & YA1 & YB2 & YB3 & YA4 & ZA1 & ZA2 & $\mathrm{ZC} 3$ \\
\hline \multicolumn{11}{|c|}{ Remains of cereals, pulses, oil/fibre seeds and fruits } \\
\hline Total number of samples in each trench & 5 & 2 & 7 & 1 & 3 & 1 & 1 & 1 & 7 & 6 \\
\hline Hordeum vulgare & 0 & 0 & 6 & 2 & 33 & 0 & 0 & 0 & 0 & 0 \\
\hline Triticum aestivum & 0 & 0 & 0 & 0 & 0 & 0 & 0 & 0 & 2 & 0 \\
\hline Oryza sativa & 121 & 6 & 36 & 3 & 10 & 1 & 0 & 0 & 103 & 86 \\
\hline Paspalum scrobiculatum & 0 & 0 & 0 & 0 & 0 & 0 & 3 & 0 & 0 & 1 \\
\hline Panicum sp. & 0 & 0 & 0 & 0 & 0 & 0 & 1 & 0 & 0 & 0 \\
\hline Pisum sativum & 92 & 0 & 55 & 10 & 0 & 0 & 0 & 1 & 0 & 16 \\
\hline Lens culinaris & 15 & 0 & 6 & 0 & 2 & 0 & 0 & 0 & 2 & 12 \\
\hline Lathyrus sativus & 2 & 0 & 0 & 0 & 2 & 0 & 0 & 0 & 0 & 0 \\
\hline Macrotyloma uniflorum & 6 & 1 & 0 & 0 & 0 & 0 & 0 & 0 & 0 & 3 \\
\hline Vigna $\mathrm{cf}$. radiate & 62 & 0 & 77 & 0 & 0 & 0 & 0 & 0 & 5 & 14 \\
\hline Lablab cf. purpureus & 0 & 0 & 1 & 0 & 0 & 0 & 0 & 0 & 0 & 0 \\
\hline Cajanus cajan & 0 & 0 & 0 & 0 & 0 & 0 & 0 & 0 & 1 & 0 \\
\hline Linum usitatissimum & 0 & 0 & 0 & 0 & 0 & 0 & 0 & 0 & 3 & 0 \\
\hline Gossypium sp. & 1 & 10 & 2 & 0 & 0 & 0 & 0 & 0 & 3 & 5 \\
\hline Carissa carandas & 0 & 0 & 1 & 0 & 0 & 0 & 0 & 0 & 0 & 0 \\
\hline Ziziphus nummularia & 37 & 3 & 20 & 11 & 3 & 0 & & 0 & 1 & 24 \\
\hline Emblica sp. & 11 & 0 & 0 & 0 & 0 & 0 & 0 & 0 & 0 & 0 \\
\hline Total -935 & 347 & 20 & 204 & 27 & 50 & 1 & 4 & 1 & 120 & 161 \\
\hline \multicolumn{11}{|c|}{ Remains of minor cereals, weeds and other wild taxa recorded } \\
\hline Total number of samples in each trench & 5 & 2 & 7 & 1 & 3 & 1 & 1 & 1 & 7 & 6 \\
\hline Oryza cf. rufipogon & 0 & 0 & 0 & 0 & 0 & 0 & 0 & 0 & 0 & 4 \\
\hline Setaria sp. & 55 & 0 & 3 & 0 & 0 & 0 & 0 & 0 & 6 & 6 \\
\hline Echinochloa sp. & 0 & 15 & 0 & 0 & 0 & 0 & 0 & 0 & 0 & 2 \\
\hline Vicia sativa & 0 & 0 & 0 & 0 & 1 & 0 & 0 & 0 & 4 & 1 \\
\hline Rumex sp. & 0 & 0 & 4 & 0 & 0 & 0 & 0 & 0 & 0 & 0 \\
\hline Andropogon sp. & 1 & 7 & 2 & 2 & 0 & 0 & 0 & 0 & 0 & 12 \\
\hline Acacia $\mathrm{sp}$ & 1 & 0 & 0 & 0 & 0 & 0 & 0 & 0 & 0 & 0 \\
\hline Total -126 & 57 & 22 & 9 & 2 & 1 & 0 & 0 & 0 & 10 & 25 \\
\hline
\end{tabular}

The vegetation of the Vidarbha region is dominated by evergreen, deciduous and thorny scrub forests. The vegetation around the study area mainly comprises of mango (Mangifera indica), beheda (Terminalia belerica), sisum (Dalbergia latifolia), jambul (Syzygium cuminii), bamboo (Dendrocalamus stirctus), jujube (Ziziphus sp.), etc. ${ }^{26}$. The principal crops in and around Vidarbha are Triticum aestivum, Hordeum vulgare, Oryza sativa, Sorghum bicolor, Pennisetum glaucum, Vigna radiata, Vigna mungo, Sesamum indicum, Gossypium arboreum and vegetables.

\section{Material and methods}

\section{Sampling and sample processing}

In order to understand the plant-based subsistence economy of ancient inhabitants, 34 samples were collected during the course of excavation in 2017-18 using standard water flotation technique ${ }^{29}$. Soil from the cultural deposits, pits, floor and hearth was put poured into a tub and agitated to retrieve the carbonized and silicified plant remains (grains/seeds/fruits) using 30 mesh $(0.5 \mathrm{~mm})$ geological sieve. The recovered samples ranged in volume from 1 to 15 litre; the total volume of the floated soil was 835 litre. Floats were then collected in a cloth, tagged and allowed to dry in the shade and packed in polythene bags for laboratory analysis.

\section{Sorting and identification}

Charred materials were sorted out and identified in the laboratory making use of the institutional reference collection and published literature ${ }^{30-32}$. The samples consisting of carbonized botanical remains, modern rootlets, shells and charcoal were examined under a stereobinocular microscope (LeicaZ6AO), and sorted into different species levels (Table 1). In all, 1060 carbonized seeds were recovered from 34 samples (including whole or fragment or partly). Majority of the plant remains recovered were a mixture of carbonized grains, seeds and fruits of cultivated and wild plants along with a bulk of wood charcoal pieces. Out of the total number of carbonized seeds, $935(88.1 \%)$ represent cultivated plants and $126(11.8 \%)$ represent weeds and wild taxa. The macroremains representing 26 different taxa were identified, all the plant remains were carbonized. Absolute count of plant taxa and ubiquity were used to analyse the data 
Table 2. Abundance and ubiquity of charred botanical remains from Rithi Ranjana

\begin{tabular}{|c|c|c|c|}
\hline Taxon & Absolute count & Present in sample & Ubiquity (\%) \\
\hline \multicolumn{4}{|l|}{ Cereals } \\
\hline H. vulgare & 41 & 5 & 14 \\
\hline T. aestivum & 2 & 1 & 2 \\
\hline O. sativa & 366 & 25 & 73 \\
\hline Paspalum sp. & 4 & 2 & 5 \\
\hline Panicum sp. & 1 & 1 & 2 \\
\hline \multicolumn{4}{|l|}{ Pulses } \\
\hline P. sativum & 174 & 14 & 41 \\
\hline L. culinaris & 37 & 12 & 35 \\
\hline L. sativus & 4 & 3 & 8 \\
\hline M. uniflorum & 10 & 3 & 8 \\
\hline Vigna cf. radiata & 158 & 24 & 70 \\
\hline Lablab cf. purpureus & 1 & 1 & 2 \\
\hline C. cajan & 1 & 1 & 2 \\
\hline \multicolumn{4}{|l|}{ Oil/fiber yielding crop } \\
\hline L. usitatissimum & 3 & 1 & 2 \\
\hline Gossypium sp. & 21 & 8 & 23 \\
\hline \multicolumn{4}{|l|}{ Fruits and nuts } \\
\hline C. carandas & 1 & 1 & 2 \\
\hline Z. nummularia & 99 & 19 & 55 \\
\hline Emblica sp. & 11 & 2 & 5 \\
\hline \multicolumn{4}{|c|}{ Minor cereals/weeds and other wild taxa } \\
\hline Oryza cf. rufipogon & 4 & 1 & 2 \\
\hline Setaria $\mathrm{sp}$ & 67 & 5 & 14 \\
\hline Echinochloa sp. & 9 & 3 & 8 \\
\hline V. sativa & 17 & 2 & 5 \\
\hline Rumex sp. & 4 & 1 & 2 \\
\hline Andropogon sp. & 24 & 6 & 17 \\
\hline Acacia sp. & 1 & 1 & 2 \\
\hline Total & 1060 & 143 & \\
\hline
\end{tabular}

Table 3. AMS radiocarbon dates of botanical remains recovered from Rithi Ranjana at $2 \sigma(95.4 \%)$ probability

\begin{tabular}{lcccc}
\hline Lab id & Sample ID & \multicolumn{1}{c}{ Material } & Depth (masl) & Radiocarbon age (BP) \\
\hline D-AMS 028248 & RJN XA1/2/3 & Charred rice $($ O sativa) & $311.44-311.30$ & $2309 \pm 24$ \\
D-AMS 028247 & RJN YB2/7/7 & Charred barely $($ H. vulgare $)$ & $310.90-310.86$ & $2327 \pm 29$ \\
D-AMS 028249 & RJN A-1/1/9 & Charred field pea $(O$. sativum $)$ & 310.22 & $407-360$ BC \\
D-AMS 028244 & RJN A-1/1/7 & Charred rice $(O$. sativa $)$ & $310.51-310.49$ & $2334 \pm 26$ \\
\hline
\end{tabular}

$(\text { Table } 2)^{33}$. Like artifacts, seeds can also be identified and their utility can be inferred ${ }^{34}$.

\section{Radiocarbon dating}

The absolute chronology of the archaeological site is based on dating of different habitation layers in different trenches. Samples of four charred grains/seeds from different depths recovered through flotation were dated by direct AMS, USA (D-AMS). The sample preparation method undertaken at D-AMS was used with a standard acid-base-acid (ABA) followed by combustion and graphitization prior to AMS dating ${ }^{35}$. Final ${ }^{14} \mathrm{C}$ ages were calibrated using the probability method of OxCal v 4.2.4 (ref. 36, 37) and the IntCal 13 dataset $^{38}$. The $2 \sigma$ range corresponds to $95.4 \%$ confidence limits. The carbonized seeds of rice and pea from trench A-1 used for dating yielded age ranges of 770-508 (D-AMS028244) and 510-383 (D-AMS028249) cal BC suggesting the beginning of Early Iron Age around $770 \mathrm{BC}$ at this site. Table 3 provides a summary of these dates.

\section{Results}

\section{Radiocarbon chronology}

The resulting dates support the identification of cultural sequence at the site. A Bayesian model of the obtained 


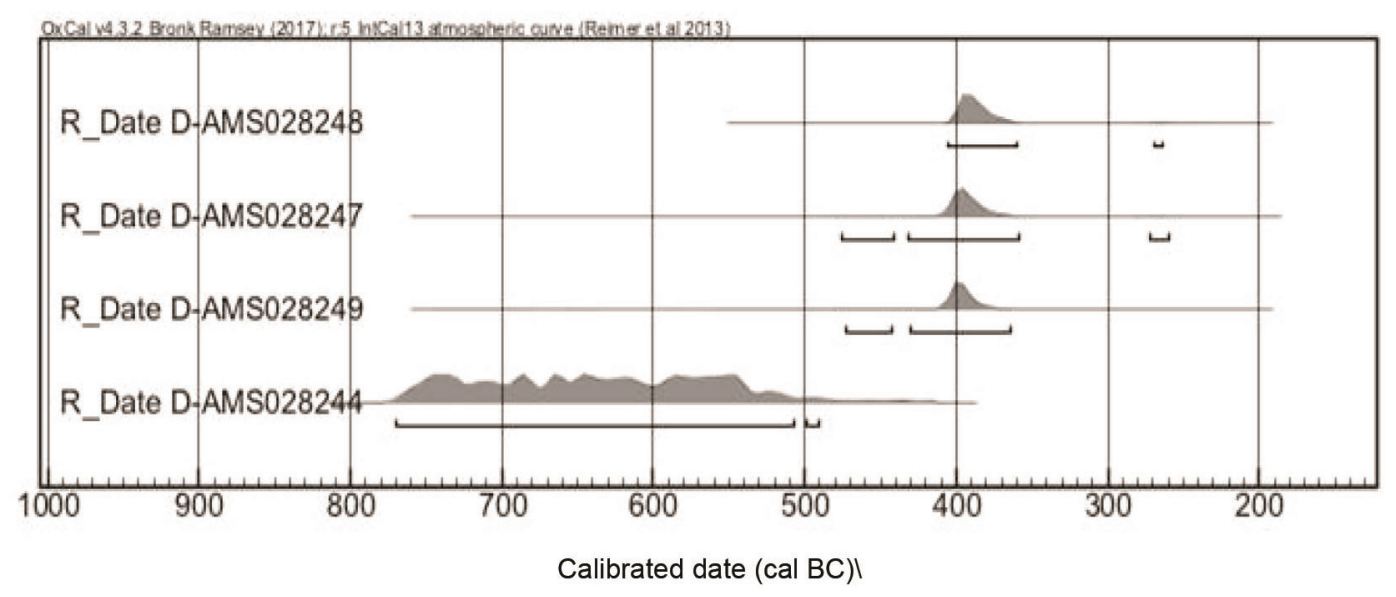

Figure 4. Bayesian sequence model of radiocarbon dates based on OxCal. v. 4.3 .2 (ref. 37) and IntCal13 atmospheric curve ${ }^{38}$.

Table 4. Measurement and index values of botanical remains from Rithi Ranjana

\begin{tabular}{|c|c|c|c|c|c|c|c|c|}
\hline Taxon & $n$ & $n m$ & $L(\mathrm{~mm})$ & $B(\mathrm{~mm})$ & $T(\mathrm{~mm})$ & $L: B$ & $L: T$ & $B: T$ \\
\hline H. vulgare & 41 & 12 & $5.34(4.59-6.15)$ & $3.53(3.12-4.41)$ & $2.56(1.7-2.5)$ & 1.81 & 2.08 & 1.37 \\
\hline T. aestivum & 2 & 2 & $5.14(4.73-5.5 .26)$ & $3.41(2.57-3.50)$ & $1.86(1.4-2.0)$ & 1.50 & 2.76 & 1.84 \\
\hline O. sativa & 366 & 50 & $5.76(5.14-6.03)$ & $2.20(1.89-2.46)$ & $1.48(1.3-1.7)$ & 2.61 & 3.89 & 1.48 \\
\hline Paspalum sp. & 4 & 4 & 1.64 & 1.89 & 1.49 & 0.86 & 1.10 & 1.26 \\
\hline Panicum sp. & 1 & 1 & 1.89 & 1.82 & 0.67 & 1.03 & 2.82 & 2.71 \\
\hline P. sativum & 174 & 30 & $3.85(3.66-4.16)$, in diameter & & & & & \\
\hline L. culinaris & 37 & 10 & $3.18(3.10-3.28)$ & $2.58(2.02-2.79)$ & $1.4(1.0-1.7)$ & 1.23 & 2.27 & 1.84 \\
\hline L. sativus & 4 & 4 & $3.56(3.02-3.89))$ & $3.78(3.07-4.16)$ & $3.34(3.0-3.7)$ & 0.94 & 1.06 & 1.13 \\
\hline M. uniflorum & 10 & 10 & $4.27(4.21-4.35)$ & $3.14(2.98-3.28)$ & $1.32(1.21-1.40)$ & 1.35 & 3.23 & 2.37 \\
\hline Vigna $\mathrm{cf}$. radiata & 158 & 30 & $3.44(2.55-4.30)$ & $2.28(1.79-2.95)$ & $3.12(2.81-3.50)$ & 1.50 & 1.10 & 0.73 \\
\hline Lablab cf. purpureus & 1 & 1 & 5.35 & 4.43 & 2.74 & 1.20 & 1.61 & 2.26 \\
\hline L. usitatissimum & 3 & 2 & $4.26(4.03-4.38)$ & $2.23(2.4-2.72)$ & $1.6(1.2-2.0)$ & 1.91 & 2.66 & 1.39 \\
\hline Gossypium sp. & 21 & 10 & $4.62(4.62-4.68)$ & $3.16(3.02-3.24)$ & $3.34(3.2-3.45)$ & 1.46 & 1.38 & 0.94 \\
\hline Emblica $\mathrm{sp}$ & 11 & 4 & $5.21(4.94-5.40)$ & $2.52(2.44-2.59)$ & $2.35(2.1-2.7)$ & 2.06 & 2.21 & 1.07 \\
\hline Carissa carandas & 1 & 1 & 2.66 & 3.08 & & 0.80 & & \\
\hline Z. nummularia & 99 & 25 & $6.28(5.94-6.35)$ & $5.23(4.28-5.88)$ & & 1.20 & & \\
\hline
\end{tabular}

$n$, Number of grains/seeds/fruits; nm, Number of grains/seeds/fruits measured; $L$, Length, $B$, breadth and $T$, thickness.

dates was developed using OxCal v4.3.2 (ref. 37) and r.5IntCal13 atmospheric curve ${ }^{38}$ (Figure 4). In addition, the archaeological artifacts like pottery and terracotta from different cultural layers testify the cultural sequence.

\section{Archaeobotanical evidence and identification}

The identified plant remains include cereals (Hordeum vulgare, Oryza sativa, Oryza cf. rufipogon, Triticum cf. aestivum); pulses (Vigna radiata, Lathyrus sp., Macrotyloma uniflorum, Pisum sativum, Lens culinaris, Lablab purpureus, Cajanus cajan), a few minor cereals (Paspalum sp., Panicum sp., Setaria sp., Echinochloa sp.); oil and fibre (Gossypium sp., Linum sp.) plants. Fruits (Ziziphus sp., Emblica sp. and Carissa carandas) were also recorded (Figure 5). In addition, a few weeds and other wild taxa which as an admixture with these economically important remains were also retrieved (Table 2). The most ubiquitous finds were those of $O$. sativa. The co-occurrence of millets (Setaria sp., Paspalum sp., Panicum sp. and Echinochloa sp.) with wild and cultivated rice suggests that these millet-grasses were also gathered/ cultivated for consumption. Table 4 presents the information related to the measured morphometrics (length, breadth and width) of the taxa.

\section{Discussion}

\section{Background: socio-economic and agricultural development in the Deccan region}

The expansion of Harappan/Indus culture from northwestern India in some areas of the hinterland of Maharashtra must have provided a base for economic growth in the subsequent Chalcolithic phases as revealed by a few sites 
(a)
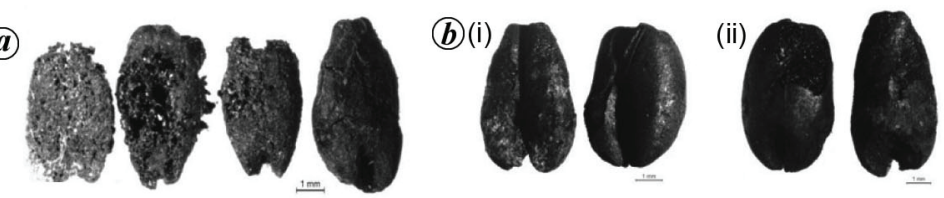

(c)
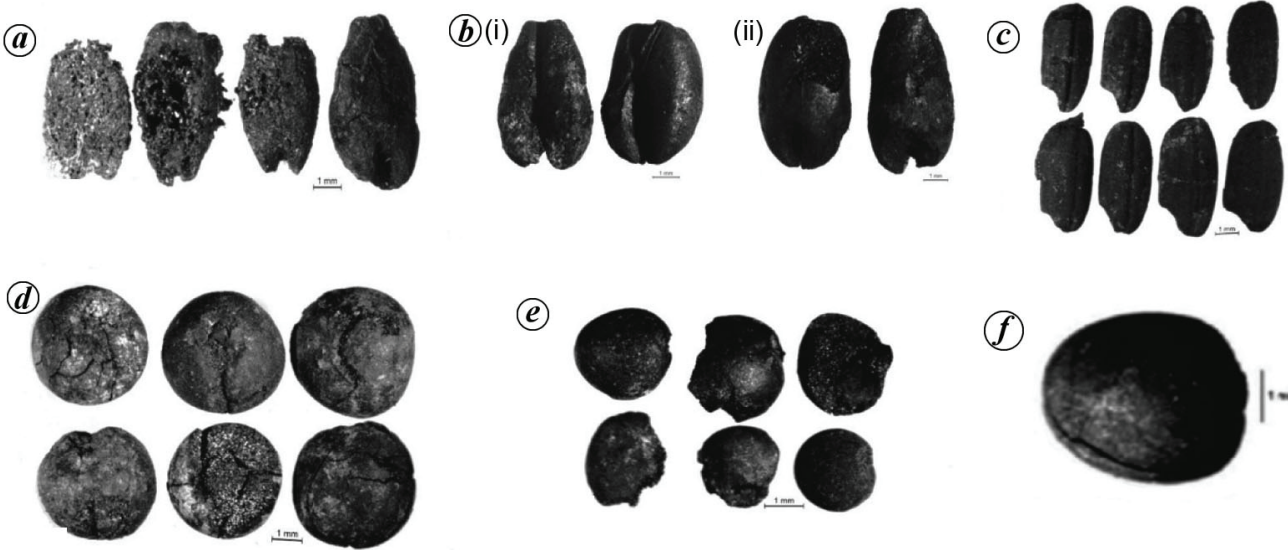

(e)

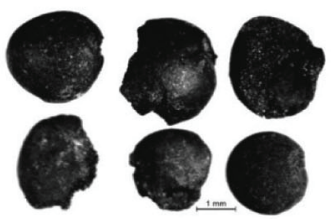

(g)
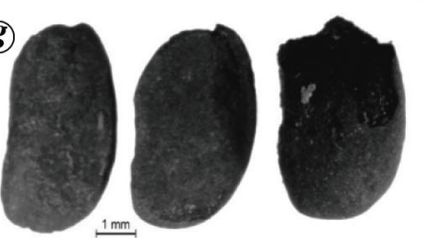

(b)
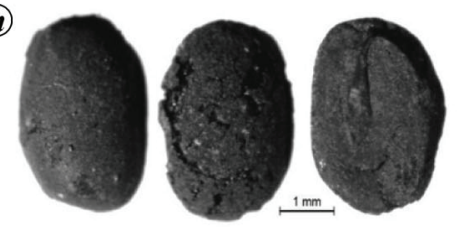

(i)

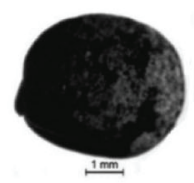

(k)

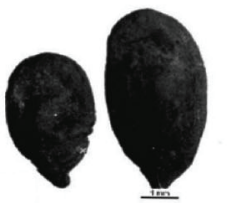

(1)

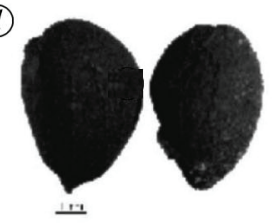

(0)
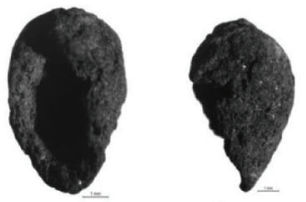

(D)

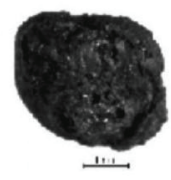

(4)

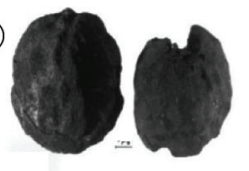

(s)

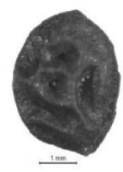

(t)

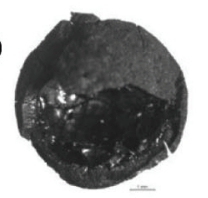

(14)
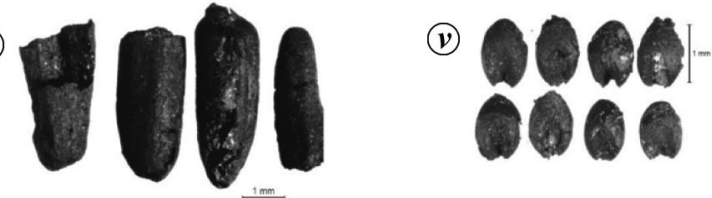

(14)

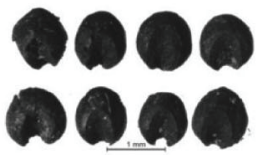

(x)

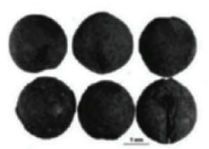

(D)

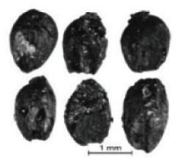

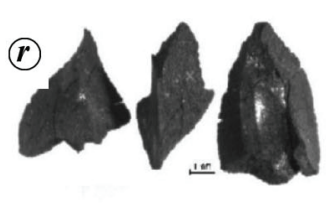

(1)

(f)

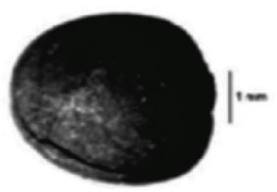

(i)

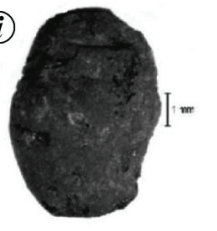

(ii) 00

(i)

(2)

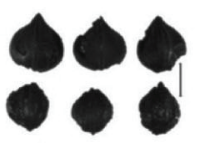

Figure 5. Botanical macroremains of cultivars, minor cereals and wild taxa: (a) Hordeum vulgare, (b) Triticum aestivum - (i) ventral view and (ii) dorsal view, (c) Oryza sativa, (d) Pisum sativum, (e) Lens culinaris, (f) Lathyrus sativus, (g) Macrotyloma uniflorum, (h) Vigna cf. radiata, (i) Lablab purpureus, (j) Cajanus cajan, (k) Linum usitatissimum, (l) Gossypium sp., (m) Paspalum sp., (n) Panicum cf. milliaceum, (o) Indeterminate, (p) Carissa carandas, (q) Ziziphus nummularia, (r) Emblica sp., (s) Acacia sp., (t) Indeterminate, (u) Oryza cf. rufipogon (wild rice), (v) Setaria sp., (w) Echinochloa sp., (x) Vicia sativa, (y) Andropogon sp. and (z) Rumex sp.

excavated and studied for agricultural remains (Table $5)^{39}$. The Chalcolithic cultures share a common level of agricultural economy and technology. Due to the succeeding Late Harappan (Indus culture) and Malwa cultures at Daimabad, Maharashtra, it may be surmised that wheat and barley may have been grown along with several of leguminous crops. The excavations at Daimabad and Inamgaon have revealed separate houses of a craftsman and a priest, suggesting the existence of ranked society around $1600 \mathrm{BC}$. The religious complexes excavated 
at Daimabad, Maharashtra and Dangwada, Madhya Pradesh $^{40}$ indicate that the Malwa Excavations at Inamgaon and Daimahad suggest that copper was obtained from southeastern Rajasthan and molluscan shells from Saurashtra through trade contacts ${ }^{41}$. Food grains from Inamgaon and Daimabad included wheat (Triticum aestivum and T. sphaerococcum), barley (Hordeum vulgare), finger millet (Eleusine coracana), lentil (Lens culinaris), field pea (Pisum arvense), grass pea (Lathyrus sativus), horse gram (Macrotyloma uniflorum), cow pea (Vigna unguiculata), hyacinth bean (Lablab purpureus) and black gram (Vigna mungo). Fruits of Ziziphus jujuba, Phoenix sylvestris and Syzygium cuminii, were also identified $^{42-45}$. It has been argued that the Malwa farmers in place of iron ploughs, could have not successfully exploited the hard and sticky black cotton soil for agriculture purpose in Maharashtra ${ }^{46}$. However, according to Wallace $^{47}$, black cotton soil breaks easily as a result of its shrinkage and expansion cycle, and a wooden hoe is sufficient to turn the soil ${ }^{46}$. Malwa people domesticated cattle, sheep and goat. Bones of sambar, chital, blackbuck, mongoose and hare suggest the hunting of wild fauna to supplement the protein requirement in their $\operatorname{diet}^{48}$.

The succeeding Jorwe culture (ca. 1400-900 BC) on the banks of River Pravara in Ahmednagar district, Maharashtra shows the settlement patterns, socio-political organization, technology, religious beliefs and exchange networks better than other Chalcolithic cultures in the Deccan and Central India ${ }^{41}$. Jorwe people traded with many of their contemporaries, including the huntergatherers. They obtained gold and ivory from Karnataka, copper from Rajasthan, and molluscan shells and amazonite from the Saurashtra coast, Gujarat. Copper may also have come from Amreli mines in Gujarat ${ }^{41}$. Within the Jorwe culture itself, large centres like Inamgaon and Daimabad may have served for regional exchange and also as redistributive centres under the administrative control of chiefdoms. These farming communities used painted and wheel-made pottery. Copper objects, gold ornaments, crucibles and tongs of copper for the goldsmiths, chalcedony drills used to perforate the beads of semiprecious stones and copper drills for ivory beads indicate the technical advancement attained by the Jorwe people. Lime-making was a flourishing industry of the Jorwe communities, as testified by Inamgaon evidence $^{41,49}$. Cotton and flax were used by Jorwe people in Maharashtra during that time. This inference is based on the discovery of beads strung upon a thread of silk with a cotton nep from Nevasa in Ahmednagar district and a second such string in a similar context at Chandoli in Pune district, which had a thread of flax or linseed ${ }^{50}$. The domesticated animals of the Jorwe people included cattle, sheep, goat, buffalo and pig ${ }^{48}$.

Further excavations at Apegaon and Tuljapur Garhi in Maharashtra give us a fair idea of cultivation of different species of wheat, barley, rice, jowar, kodon, ragi, foxtail millet, greengram, blackgram, lentils, grass-pea, fieldpea, pigeonpea, chickpea, horse-gram, hyacinth bean, safflower and linseed ${ }^{44,45}$. However, the prehistory of agriculture development in the Vidharba region based on direct dates is obscure. The Rithi Ranjana site consists of an alluvium area, black-brown soil and iron artifacts such as hoes, sickles, mullers, ploughshares, etc. providing excellent proof of agricultural activities, suggesting agriculture was the main mode of subsistence during the Early Iron Age. Data from sites showing the evidence of agriculture economy are summarized in Table 5, and uncover affinities with other rural settlement in the Vidarbha area and beyond.

\section{Implications for understanding palaeodiet and palaeo-agriculture during Early Iron Age at Rithi Ranjana}

The archaeobotanical assemblage includes cereals, pulses, oilseeds, fibre crops and fruits. The most abundant crop is O. sativa (39\%) followed by $H$. vulgare (4\%) and $T$. aestivum (1\%). Besides cereals, a large number of pulses, especially Vigna cf. radiata (17\%), P. sativum (19\%) and L. culinaris (4\%) along with L.O sativus, $M$. uniflorum, L. purpureous and C. cajan (>1\%) have been recorded. The oil/fibre seeds are represented by $L$. usitatissimum and Gossypium sp. (2\% each). Furthermore, the remains of fruits and medicinal plants such as Emblica sp. and Ziziphus sp. suggest that horticultural practices and medicinal knowledge were in vogue during that time. Besides crops, minor cereals and weeds and wild taxa (11\%) recovered in the mixture are also of considerable importance for acquiring knowledge of ground vegetation, state of agricultural fields, and the fallow and grasslands in the vicinity of the ancient settlement.

Overall the crop assemblage at Rithi Ranjana was dominated by rice $(n=366)$ and pulses $(n=381)$ (Figure $6 a$ ), representing around $60 \%$ of the total assemblage, with minor crops and other weed and wild taxa approximately $10 \%$ each (Figure $6 \mathrm{~b}$ ).

Barley was already in cultivation along with wheat in the 6 th millennium BCE in Baluchistan region ${ }^{51}$. Barley and wheat are the most common cereals recovered from the archaeological sites in the Indian subcontinent during Neolithic, Chalcolithic, Iron Age and early historic times ${ }^{52-54}$. However, these cereals are poorly represented in the western region either from Harappan or Late/Post-Urban or Iron Age levels. Barley, which is more adaptable and best suited to dry zone with less irrigation was found in most of the sites. Barley in Rithi Ranjana would certainly have not arrived before 2000 BC. Most of the species of cultivated cereals and pulses have come to light from Chalcolithic Inamgaon (ca. 1600-700 BC) and Daimabad during middle and late phases of the 2 nd millennium $\mathrm{BC}$ (refs 42 and 43). Pigeon pea has a prominent archaeological record as noted from Megalithic Bhagimohari 


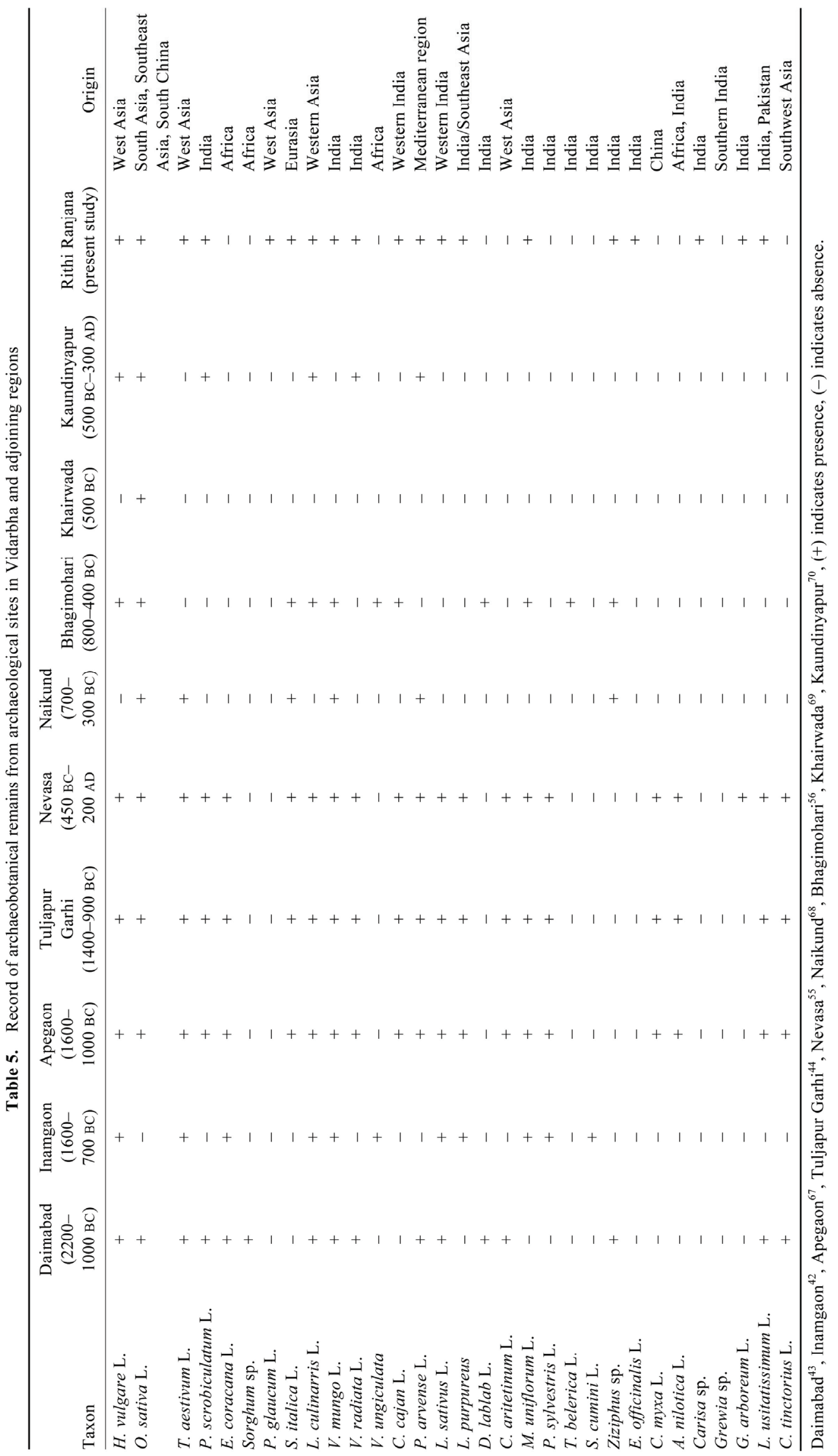


(ca. 800-400 BC) in Nagpur district and Indo-Roman levels (ca. 50-150 BC) at Nevasa, Ahmednagar district $^{55,56}$.

Cultivation of oil/fibre-yielding crops at this site is evidenced by Linum cf. usitatissimum and Gossypium sp. Linseed belongs to Near Eastern group of crops, where evidences of its cultivation go as far back as those of wheat and barley. Archaeobotanical evidence in the Indian region goes back to the Early Harappan (2850 2600 BC) at Kunal, Haryana and Neolithic times in the Ganga Plain ${ }^{53,57}$. The evidence of flax is from the Early Jorwe phase, ca. $1500 \mathrm{BC}$ in Maharashtra ${ }^{58}$. Thus, flax appears to lag behind the other Southwest Asian crops on Chalcolithic location in Maharashtra. Cotton ( $G$. arboreum/herbaceum) occupied the foremost position among commercial crops of the Harappans. According to Santhanam and Hutchinson, cotton textile in the Indus civilization was the product of 'sophisticated textile-craft'. It has been recorded at Navdatoli in the Chalcolithic period of Maharashtra ${ }^{50}$. Evidence of cotton seeds draws our attention towards economic transformation and about the advanced nature of agriculture. Thus, non-staple food plants may have acted as commodities of trade and united communities together.

The presence of kharif (summer) and rabi (winter) crops in the archaeobotanical record suggests that agri
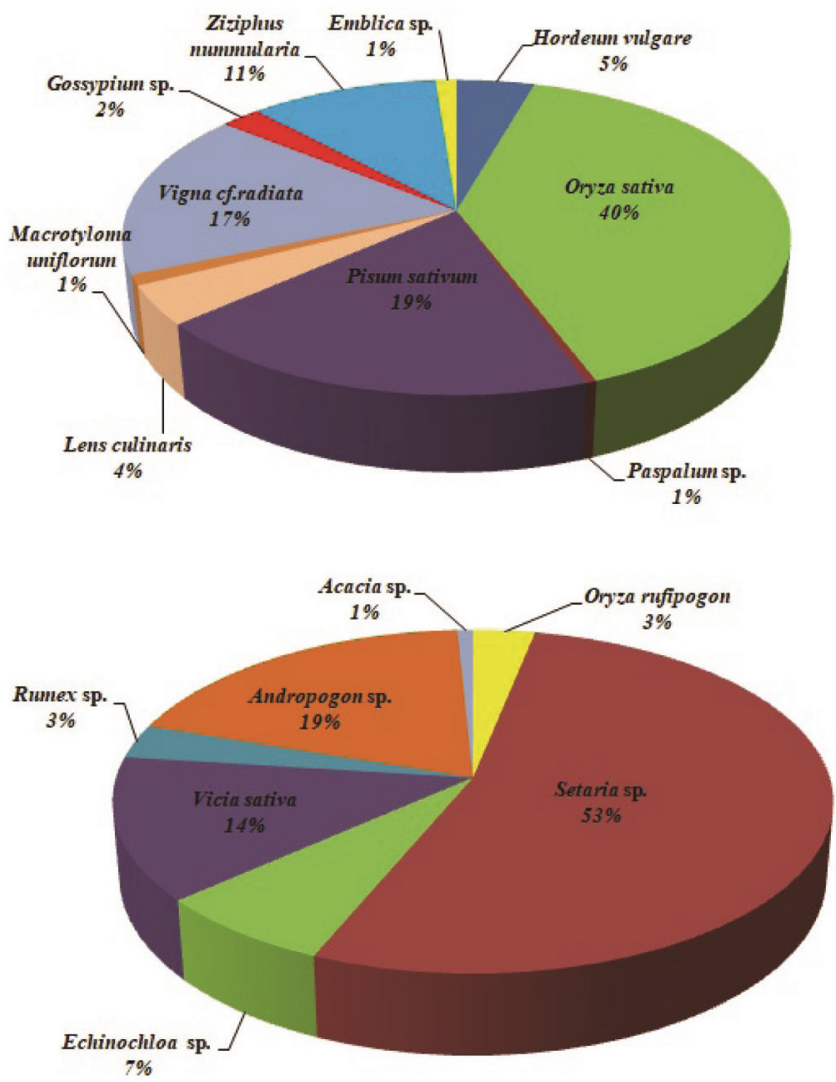

Figure 6. Relative proportion of (a) field crops and (b) minor cereals, weeds and wild taxa. cultural practices were continued from the preceding cultural phases all around the year during the Early Iron Age too. The remains of double-cropping system provide empirical evidence for a rich and varied plant economy of settlers in the Early Iron Age (Table 6) and denote how these settlers adopted and assimilated into their farming practices the founder elements of Neolithic, Chalcolithic and Iron Age cultures across the subcontinent by direct or indirect contacts. Rice was the primary crop and accounted for $56 \%$ of the total winter and summer crop assemblage. Rice, a crop of the Ganga Plain is reported to be cultivated from northwest, northern, central and southern India ${ }^{52,54,57,60-63}$. Based on regional dataset from the semi-arid region, the spread of rice by ca. $500 \mathrm{BC}$ may have relied on seasonal rainfall and not supported by irrigated paddy field as considered earlier ${ }^{64}$. Monsoonal variability would have caused an increase in rainfall for significant non-irrigated wet-rice agriculture. The abundance of rice in the total assemblage suggests that it was the principal crop at Rithi Ranjana and the Vidarbha region. Charred rice grain from the Chalcolithic phase with a radiocarbon date of $3083 \pm 29(3370-3210$ cal BP) at Suabarei, surmises that rice spread to the northwest region through coastal lowland Odisha ${ }^{65}$. The cumulative data revealed that both winter and summer crops were part of the agricultural system, suggesting favourable climatic conditions suitable for the diversification of crops.

Jujube (Z. nummularia) and emblic myrabolan (Indian gooseberry -E. officinalis) in the assemblage, both likely from South Asian domesticates along with $C$. carandas. Evidence of E. officinalis and Z. nummularia, suggests their possible use for medicinal purposes. Emblica fruits are sour and astringent, cooling and diuretic. They are rich in ascorbic acid. E. officinalis is extensively used as adjuncts to other medicines for a number of ailments in Ayurveda $^{66}$. Ziziphus fruits are also edible. They are often dried and used in native medicines as cooling, anodyne and tonic ${ }^{66}$.

Few weedy taxa were also recorded and quantified. The remains of minor cereals and weeds and wild species (11\%) retrieved with cultivated crops are also of

Table 6. Seasonality of botanical remains recorded from Rithi Ranjana

\begin{tabular}{lll}
\hline \multirow{2}{*}{ Plant remains } & \multicolumn{2}{c}{ Cropping season } \\
\cline { 2 - 3 } Cereals & Winter & Summer \\
& H. vulgare & O. sativa \\
& T. aestivum & Paspalum $\mathrm{sp}$. \\
& & Panicum $\mathrm{sp}$. \\
Pulses & P. sativum & S. italic \\
& L. sativus & V. radiata/mungo \\
& & M. uniflorum \\
Fruits & Z. nummularia & Emblica $\mathrm{sp}$. \\
Oil/fibre-yielding crops & L. usitatissimum & Gossypium $\mathrm{sp}$. \\
\hline
\end{tabular}




\section{RESEARCH ARTICLES}

significance for acquiring palaeoecology of the surrounding, the state of the agricultural areas and the fallow and grasslands near the ancient settlement. Development of these grasses, sedges and herbs follows the rain as ephemerals, and can be considered to survive in the wellwatered and marshy regions around the ancient mound. Echinochloa sp., Setaria sp., Oryza cf. rufipogon and Andropogon sp., represent members of family Poaceae in agricultural fields. Chenopodium sp., Rumex sp., tender shoots may have been used as vegetables. The abundance of Setaria grains makes up 53\% of the total weed collection, suggesting that they had not arrived as contaminants but were collected or stored from the harvested crop. $V$. sativa is a weed of leguminous crops. These remains constitute only a fraction of the biological material. Therefore, at present, environmental reconstruction cannot be done solely on this basis.

\section{Conclusion}

The beginning of agricultural practices in the study region has been placed as early as $2000 \mathrm{BC}$ based on ceramics and cultural artifacts ${ }^{39}$, However, the direct dates of individual grains/seeds are still lacking to identify the beginning of the fully sedentary agricultural practices in this region. Detailed archaeobotanical analysis with direct dates can be used to examine issues related to diffusion and migration. The well-dated, charred macroremains from Rithi Ranjana show that the founder elements of Chalcolithic subsistence in the region continued to exist in the crop economy of Early Iron Age settlers. Thus the present study provides useful insights regarding sequential agricultural history in the semi-arid Vidarbha region of Maharashtra.

1. Moorti, U. S., Megalithic Culture of South India: Socioeconomic Perspectives, Ganga Kaveri Publishing House, Varanasi, 1994.

2. Rivett-Carnac, J. H., Prehistoric Remains in Central India, Baptist Mission Press, Calcutta, 1879.

3. Pearse, G., Notes on the excavation of a stone circle near Kamptee in Central Province of India. Ethnography Society of London, UK, 1869, pp. 428-429

4. Carey, J. J., Stone circles found near Khairwada, Wardha districts. Proc. Asiatic Soc. Bengal, 1871, 105, 238-239.

5. Hunter, G. A. P., The antiquities of Mahurziri, Shardashram Varshik. Indian Archaeol. - A Review, 1933, 5, 30-35.

6. Deo, S. B., The Vidarbha megaliths: a review. Bulletin of the Deccan College Post Graduate and Research Institute (PGRI), Pune, 1982, vol. 41, pp. 64-88.

7. Deo, S. B., The megaliths: their culture, ecology, economy and technology. Rec. Adv. Indian Archaeol., 1985, 89, 35-40.

8. Deo, S. B. and Jamkhedkar, A. P., Excavations at Naikund 1978 80, Government of Maharashtra, 1982.

9. Deglurkar, G. B. and Lad, G., Megalithic Raipur (1985-90), Deccan College PGRI, Pune, 1992.

10. Mohanty, R. K., Excavations at Mahurjhari and exploration in Vidarbha, Annual Report of Deccan College, PGRI, 2003, vol. 4, pp. 50-52.
11. Mohanty, R. K., Some important observation: excavations at Mahurjhari (2001-2004). Man Environ., 2005, 3, 106-107.

12. Mohanty, R. K. and Walimbe, S. R., A demographic approach to the Vidarbha megalithic culture. Man Environ., 1993, 18, 93-103.

13. Mohanty, R. K. and Joshi, P. S., The megalithic problem of Vidarbha: retrospect and prospect. In Spectrum of Indian Culture, Agam Kala Prakashan, Delhi, 1996, pp. 157-169.

14. Ismail, K., Excavation at Vyahad. In XXXIV Annual Conference of the Indian Society for Prehistoric and Quaternary Studies, Raipur, 2006.

15. Thakuria, T., The society and economy during Early Iron Age and Early Historic period in Deccan with special reference to beads (1000 BC to 500 AD), Ph.D. thesis, Deccan College PGRI, Pune, 2010.

16. Vaidya, S., Burials and settlements of the Early Iron Age in Vidarbha: a fresh analysis. Man Environ., 2014, 102-114.

17. Dikshit, M. G., Excavations at Kaundinyapura, The Director of Archives and Archaeology (1968), 2017.

18. Deo, S. B. and Dhavalikar, M. K., Paunar Excavation, 1967, Nagpur University, 1968.

19. Indian Archaeology: A Review 1978-79, Archaeological Survey of India, New Delhi.

20. Walimbe, S. R., Excavations at the Early Historic Site of KahaliBramhapuri, Deccan College Annual Report (2001-02), 2003, pp. 39-40.

21. Nath, A., Adam - an index to Vidarbha archaeology. New Trends Indian Art Archaeol., 1992, 1, 69-79.

22. Deo, S. B., Indian beads: a cultural and technological study. Deccan College PGRI, Pune, 2000.

23. Gogte, V. D. and Megalithic iron smelting at Naikund (Part I): discovery by three-probe resistivity survey. In Excavations at Naikund (1978-80) (eds Deo, S. B. and Jamkhedkar, A. P.), Nagpur University, 1992, pp. 52-55.

24. Sundara, A., Indian megaliths and iron. Hist. Sci., Philos. Cult. Indian Civilization, 1999, 4(1), 148-172.

25. Deotare, B. C., Joshi, P. S. and Parchure, C. N., Glimpses of ancient Maharashtra through archaeological excavations. Bharatiya Itihas Sankalan Samitee and Deccan College PBRI, Pune, 2013.

26. Dikshit, K. R., Maharashtra in Maps, Maharashtra Board of Literature and Culture, Mumbai, 1986.

27. Singh, R. L., India; A regional geography, 1971, pp. 1012.

28. Sawant, R., Review of archaeological investigations in pre-historic and historical archaeology of Vidarbha. Man Environ., 2010, 35, 45-65.

29. Pearsall, D. M., Palaeoethnobotany: A Handbook of Procedures, Academic Press, San Diego (CA), USA, 2000, 2nd edn.

30. Musil, A. F., Identification of Crop and Weed Seeds (Agriculture Handbook 219), Agricultural Marketing Service, US Department of Agriculture, 1973.

31. Martin, A. C. and Barkley, W. D., Seed Identification Manual, University of California Press, USA, 1973.

32. Harvey, E. L., Fuller, D. Q., Mohanty, R. K. and Mohanta, B., Early agriculture in Orissa: some archaeobotanical results and field observations on the Neolithic. Man Environ., 2006, 31(2), 21-32.

33. Popper, V. S., Selecting quantitative measurements in palaeoethnobotany. In Current Palaeoethnobotany (eds Hastorf, C. A. and Popper, V. S.), University of Chicago Press, Chicago, USA, 1988, pp. 53-71.

34. Weber, S. A., Seeds of urbanism: palaeoethnobotany and the Indus civilization. Antiquity, 1999, 73, 813-826.

35. Ramsey, C. B., Dee, M. W., Rowland, J. M., Higham, T. F., Harris, S. A., Brock, F. and Shortland, A. J., Radiocarbon-based chronology for dynastic Egypt. Science, 2010, 328(5985), 1554-1557.

36. Bronk, R. C. and Lee, S., Recent and planned developments of the program OxCal. Radiocarbon, 2013, 55, 720-730. 
37. Bronk, R., Methods for summarizing radiocarbon datasets. Radiocarbon, 2017, 59, 1809-1833.

38. Reimer, P. J. et al., IntCal13 and Marine13 radiocarbon age 0-50,000 years cal BP. Radiocarbon, 2013, 55, 1869-1887.

39. Saraswat, K. S., Archaeobotanical remains in ancient cultural and socio-economical dynamics of the Indian sub-continent. Palaeobotanist, 1992, 40, 514-545.

40. Wakankar, V. S. and Khare, M. D., Dangwada excavation (Ujjain). In Malwa Through the Ages (ed. Khare, M. D.), Directorate of Archaeology and Museums, Government of M.P., Bhopal, 1981, pp. 96-98.

41. Dhavalikar, M. K., Towards an ecological model for Chalcolithic cultures of central and western India. J. Anthropol. Archaeol., 1984, 3(2), 133-158.

42. Kajale, M. D., Plant economy at Inamgaon. Man Environ., 1977, 1, 54-56.

43. Kajale, M. D., On the botanical findings from excavations at Daimabad - a Chalcolithic site in western Maharashtra. Curr. Sci., 1977, 46, 818-819.

44. Kajale, M. D., Ancient plant economy at Chalcolithic Tuljapur Garhi, district Amraoti, Maharashtra. Curr. Sci., 1988, 57, 377379 .

45. Vishnu-Mittre, S. A., Chanchala (1986), Ancient plant economy at Daimabad. Diamabad 1979, 1986, vol. 83, pp. 588-627.

46. Kosambi, D. D., The beginning of the Iron Age in India. J. Econ. Soc. Hist. Orient, 1963, 6, 309-318.

47. Wallace, R., India in 1887. Oliver and Boyd, London, 1888.

48. Misra, V. N., Prehistoric human colonization of India. J. Biosci., 2001, 26(4), 491-531.

49. Ansari, Z. D., Lithic drill-heads from Inamgaon. In Bulletin of the Deccan College Research Institute, Pune, 1978, vol. 38, pp. 10 12.

50. Gulati, A. N., A note on the early history of silk in India, Poona, 1961, pp. 53-59.

51. Jarrige, J. F. and Meadow, R. H., The antecedents of civilization in the Indus Valley. Sci. Am., 1980, 243, 102-110.

52. Pokharia, A. K., Pal, J. N. and Srivastava, A., Plant macro-remains from Neolithic Jhusi in Ganga Plain: evidence for grain-based agriculture. Curr. Sci., 2009, 97(4), 564-571.

53. Pokharia, A. K., Sharma, S., Tripathi, D., Mishra, N., Pal, J. N., Vinay, R. and Srivastava, A., Neolithic-early historic (2500200 BC) plant use: the archaeobotany of Ganga Plain, India. Quaternary Int., 2017, 443, 223-237.

54. Pokharia, A., Floral remains: on the record of plant remains at Harappan settlement at Kanmer, subsistence economy with a change. Excavation at Kanmer 2005-2008, 2012, 9, 795-818.

55. Kajale, M. D., Ancient grains from excavation at Nevasa (19591960), Maharashtra. Geophytology, 1977, 7(1), 98-106.

56. Kajale, M. D., Archaeobotanical investigation on megalithic Bhagimohari, and its significance for ancient Indian agricultural system. Man Environ., 1989, 13, 87-100.

57. Saraswat, K. S. and Pokharia, A. K., Palaeoethnobotanical investigations at early Harappan Kunal. Pragdhara, 2003, 13, 105-139.

58. Janaway, R. C. and Coningham, R. A. E., A review of archaeological textile evidence from South Asia. South Asian Stud., 1995, 11, 157-174.
59. Sanathanam, V. and Hutchinson, J. B., Cotton. In Evolutionary Studies in World Crops-Diversity and Change in the Indian Subcontinent (ed. Hutchinson, J.), Cambridge University Press, Cambridge, UK, 1974, pp. 89-100.

60. Vishnu-Mittre and Savithri, R., Food economy of the Harappans. In Harrapan Civilization (ed. Possehl, G. L.), Oxford and IBH, New Delhi, 1982, pp. 205-221.

61. Willcox, G., Some differences between crops of Near Eastern origin and those from the tropics. South Asian Archaeol., 1989, 14, 291-299.

62. Fuller, D. Q., Fifty years of archaeobotanical studies in India: laying a solid foundation. In Indian Archaeology in Retrospect, Archaeology and Interactive Disciplines (eds Settar, S. and Korisettar, R.), Manohar, New Delhi, 2002, vol. XXX, pp. 247-363.

63. Saraswat, K. S. and Pokharia, A. K., Harappan plant economy at ancient Balu, Haryana. Pragdhara, 2002, 12, 153-171.

64. Kingwell-Banham, E., Dry, rainfed or irrigated? Reevaluating the role and development of rice agriculture in Iron Age-Early historic South India using archaeobotanical approaches. Archaeol. Anthropol. Sci., 2019, 11(12), 6485-6500.

65. Murphy, C., Fuller, D., Kingwell-Banham, E., Naik, S. S., Patnaik, J. K. and Gadnayak, D., Archaeobotanical investigations at Suabarei, Dist. Puri, Odisha. Curr. Sci., 2019, 116, 1373-1380.

66. Anon., The Wealth of India: Raw Materials, CSIR, New Delhi, 1976, X and XI (X-Z).

67. Kajale, M. D., On the evidence of ancient agricultural patterns during the Chalcolithic period (c. 1600-1000 BC) at Apegaon, district Aurangabad in the central Godavari Valley. In Apegaon Excavations - 1976 (eds Deo, S. B., Dhavalikar, M. K. and Ansari, Z. D.), Deccan College PGRI, Pune, 1979, pp. 50-56.

68. Kajale, M. D., First record of ancient grains in megalithic habitation context from excavation at Naikund (1978 season), dist. Nagpur, Maharashtra. In Excavations at Naikund (1978-80) (eds Deo, S. B. and Jamkhedkar, A. P.), Department of Archaeology and Museum, Government of Maharashtra, Bombay, 1982.

69. Kajale, M. D., Current status of Indian palaeoethnobotany: introduced and indigenous food plants with a discussion of the historical and evolutionary development of Indian agriculture and agricultural systems in general. In New Light on Early FarmingRecent Developments in Palaeoethnobotany (ed. Renfrew, J. M.), Edinburgh University Press, Edinburgh, UK, 1991, pp. 155-189.

70. Vishnu-Mittre, Kaundinyapura plant economy in pre-historic and historic times. In Excavations at Kaundinyapura (ed. Dikshit, M. G.), Government Central Press, Bombay, 1968, pp. 140-147.

ACKNOWLEDGEMENTS. We thank the Director General, Archaeological Survey of India, New Delhi and the Director, Birbal Sahni Institute of Palaeosciences, Lucknow, for permission and encouragement to collaborate for multidisciplinary studies.

Received 19 April 2020; revised accepted 28 January 2021

doi: $10.18520 / \mathrm{cs} / \mathrm{v} 120 / \mathrm{i} 11 / 1728-1739$ 